\title{
Label-Free Protein Group Level Quantification by LC/MS
}

National Cancer Institute

\section{Source}

National Cancer Institute. Label-Free Protein Group Level Quantification by LC/MS. NCI

Thesaurus. Code C161827.

A method for quantitating protein groups in label-free samples subjected to liquid chromatography-mass spectrometry (LC/MS). 